\title{
THE IMPACT OF POTASSIUM MANGANATE (VII) ON THE EFFECTIVENESS OF COAGULATION IN THE REMOVAL OF IRON AND MANGANESE FROM GROUNDWATER WITH AN INCREASED CONTENT OF ORGANIC SUBSTANCES
}

\author{
Izabela KRUPIŃSKA ${ }^{1}$ \\ University of Zielona Góra, Zielona Góra, Poland
}

\begin{abstract}
The article presents the results of studies concerning the impact of the method of $\mathrm{Fe}(\mathrm{II})$ ion oxidisation (dissolved oxygen and potassium manganate (VII)) on the effectiveness of coagulation in the removal of iron and manganese from groundwater with an increased content of organic substances. The efficiencies of two coagulants were compared: aluminium sulphate (VI) and polyaluminium chloride (Flokor 1.2A). Among the used methods of iron (II) oxidisation, the best effects have been achieved by potassium manganate (VII) because one of the oxidation products was manganese oxide (IV) precipitating from water. Better results in purifying the water were obtained with the use of a prehydrolysed coagulant Flokor 1.2 A than aluminium sulphate (VI).
\end{abstract}

Keywords: groundwater, iron, manganese, organic substances, potassium manganate (VII), coagulation

\section{INTRODUCTION}

Traditional air oxidation in water treatment is used for the removal of divalent forms of iron and manganese for public health purposes. These ions are frequently present in groundwaters with low oxygen content [22, 28, 29].

\footnotetext{
1 Corresponding author: University of Zielona Gora, Faculty of Civil and Environmental Engineering Institute of Environmental Engineering, Szafrana st 15, 65-246 Zielona Góra, Poland, e-mail: i.krupinska@iis.uz.zgora.pl tel. +48683282560
} 
Ferrous iron are removal from groundwater is based on transforming soluble ferrous iron (by oxidation) into insoluble ferric iron compounds. Iron is oxidized with oxygen (reaction 1) or other oxidants (potassium manganate (VII), ozone, chlorine), and with the use of bacteria that oxidise iron and manganese.

$$
2 \mathrm{Fe}^{2+}+1 / 2 \mathrm{O}_{2}+5 \mathrm{H}_{2} \mathrm{O} \rightarrow 2 \mathrm{Fe}(\mathrm{OH})_{3}+4 \mathrm{H}^{+}
$$

For bivalent manganese, autocatalysis plays an important role in oxygenation, and multiple-step mechanism has been proposed (reactions 2-4):

$$
\begin{gathered}
\mathrm{Mn}(\mathrm{II})+\mathrm{O}_{2} \underset{\mathrm{slow}}{\rightarrow} \mathrm{MnO}_{2(\mathrm{~s})} \\
\mathrm{Mn}(\mathrm{II})+\mathrm{MnO}_{2(\mathrm{~s})} \stackrel{\text { fast }}{\longrightarrow} \mathrm{Mn}(\mathrm{II}) \mathrm{MnO}_{2(\mathrm{~s})} \\
\mathrm{Mn}(\mathrm{II}) \mathrm{MnO}_{2(\mathrm{~s})}+\mathrm{O}_{2} \longrightarrow 2 \mathrm{MnO}_{2}
\end{gathered}
$$

In some cases potassium manganate (VII) is used as an oxidant (reactions 5-6).

$$
\begin{gathered}
3 \mathrm{Fe}^{2+}+\mathrm{MnO}_{4}^{-}+7 \mathrm{H}_{2} \mathrm{O} \longrightarrow 3 \mathrm{Fe}(\mathrm{OH})_{3}+\mathrm{MnO}_{2}+5 \mathrm{H}^{+} \\
3 \mathrm{Mn}^{2+}+2 \mathrm{MnO}_{4}^{-}+2 \mathrm{H}_{2} \mathrm{O} \longrightarrow 5 \mathrm{MnO}_{2}+4 \mathrm{H}^{+}
\end{gathered}
$$

This step is very efficient separation if a coagulant is added [1,29].

One of the problems with iron removal from groundwater is organic matters as they have a negative impact on the process of iron removal. Organic substances in water may interfere with the iron removal process, forming stable complexes with iron, both $\mathrm{Fe}(\mathrm{II})$ and $\mathrm{Fe}(\mathrm{III})$ and manganese. Albrektiene with colleagues [2] states that manganese doesn't form complex compounds with any fraction of organic matters. The Fe(III)-organic complexes are stronger and more stable as compared to $\mathrm{Fe}(\mathrm{II})$-organic complexes. Considerable research has been conducted to explain the chemical nature of the complexed iron. Soil scientists have been quite consistent in stating that organics which cause these complexes or peptized small metallic colloids are of relatively high molecular weight (greater than 2000), whereas water chemists generally concede that low molecular weight organics are responsible for holding iron [19, 20, 24-26, 30, 31]. Jobin and Ghosh [10] established that in the presence of organic matter, $\mathrm{Fe}(\mathrm{II})-\mathrm{Fe}(\mathrm{III})$ redox couple acts as a catalyst for the oxidation of the organic matter. In such systems, both complexation of Fe(II) and reduction of $\mathrm{Fe}$ (III) by organic matter are possible (reactions 7-9):

$$
\begin{gathered}
\mathrm{Fe}(\mathrm{II})+1 / 2 \mathrm{O}_{2}+\text { organics } \\
\mathrm{Fe}(\mathrm{III})+\text { organics (reduced) } \mathrm{Fe} \text { (III)-organic complex } \\
\longrightarrow \mathrm{Fe}(\mathrm{II})+\text { organics (oxidized) }
\end{gathered}
$$




$$
\mathrm{Fe}(\mathrm{II})+\text { organics } \longrightarrow \mathrm{Fe}(\mathrm{II}) \text {-organic complex }
$$

The relative rates of reactions 7 and 8 dictate the eventual oxidation of $\mathrm{Fe}(\mathrm{II})$ in the presence of organics. In such cases, the ferrous-ferric system acts as an electron transfer catalyst for the oxidation of organic material. Depending on the relative rates of $\mathrm{Fe}$ (II) oxygenation and $\mathrm{Fe}$ (III) reduction by organic material, substantial retardation of the over-all oxidation of $\mathrm{Fe}(\mathrm{II})$ by organic material is possible. The higher the $\mathrm{pH}$, the more the oxidation process of the $\mathrm{Fe}(\mathrm{II})$-organic complex is retarded. For example, at $\mathrm{pH} 8$, decrease in rate constant by a factor of 10 results in doubling the half-life of the $\mathrm{Fe}(\mathrm{II})$-organic complex with respect to oxidation $[8,19]$. Organic compounds lengthen the time oxidization of $\mathrm{Fe}(\mathrm{II})$ to $\mathrm{Fe}(\mathrm{III})$ and decrease its effectiveness, and oxidization products are colloidal in character [1]. They also proved that the presence of organic compounds in water makes the removal of iron much more difficult. Therefore, several various attempts have been made in order to intensify removal of iron present in combinations with organic ligands. One of the recommended methods here is the application of strong oxidisers such as chlorine, potassium manganate (VII), ozone and hydrogen peroxide instead of aeration. The inclusion of the oxidation process into the water treatment technological system is justifiable (safe) only when the oxidizing agents used do not cause the occurrence of inorganic and organic oxidation by-products harmful to human health, and products of incomplete oxidation of organic substances are removed from the water [13, 14, 17]. The use of potassium manganate (VII) should be right for oxidizing $\mathrm{Fe}$ (II) occurring in compounds with organic substances because the oxidation process is additionally aided by the adsorptive and catalytic properties of the precipitated manganese oxide (IV) $[11,12,18,21]$. There is very little information about the kinetics of oxidizing Fe(II) by means of potassium manganate (VII). It is believed that the reactions take place quickly with $\mathrm{pH}>7$. In an environment with neutral reaction, which is usual in natural water, potassium manganate (VII), is reduced to manganese oxide (IV). The hydrated colloidal manganese oxide (IV) which appears has a negative charge with $\mathrm{pH}<$ 8 , and a positive charge with $\mathrm{pH} \geq 8$ and a vast specific surface with good sorptive characteristics $[3,4,7,18]$. The use of potassium manganate (VII), is particularly favourable if there is $\mathrm{Mn}(\mathrm{II})$ in the water being purified, because apart from iron (III) hydroxide a product of the reaction is manganese oxide (IV) which catalyses the oxidization of $\mathrm{Fe}(\mathrm{II})$ and $\mathrm{Mn}(\mathrm{II})$. The catalytic oxidization of $\mathrm{Fe}$ (II) and $\mathrm{Mn}$ (II) ions makes it possible to decrease the dose of potassium manganate (VII), below stoichiometric amounts if there are not any other reduced substances $[7,18,27]$ in the water being purified. Another method suggested for treating colour waters contaminated with organic substances and 
iron compounds is the coagulation process $[5,6,9,15-18]$. It was proved that aluminium coagulants were more efficient in treatment of such water than iron salts, due to the fact that products of aluminium hydrolysis, unlike iron, do not make coloured complexes with organic substances. The total efficiency of coagulation process depends on: destabilization of colloidal pollutants and neutralization of anion charges by cation products of coagulant hydrolysis, ion exchange, surface complexing, adsorption on hydroxide particles of metals of coagulants applied and coprecipitation. The role of the mechanisms referred to above depends on $\mathrm{pH}$ reaction of the treated water, a quantity and charge of the products of coagulant hydrolysis as well as the initial concentration and form of organic substances [17, 32]. In recent years, prehydrolyzed aluminium coagulants, e.g. polyaluminium chloride and polyaluminium sulphate have been developed and researched. It has also been found that polymerised polyaluminium chlorides are more effective at removing organic substances and reducing turbidity than aluminium sulphate (VI) [5, 23, 14-17]. Better effectiveness of prehydrolysed aluminium coagulants is caused by the presence of polymeric aluminium complexes with large positive charges, which effectively destabilise and bridge the coloured organic pollution being remove [6].The article presents the results of studies concerning the impact of the method of $\mathrm{Fe}$ (II) ion oxidisation (dissolved oxygen and potassium manganate (VII)) on the effectiveness of coagulation in the removal of iron and manganese from groundwater with an increased content of organic substances.

\section{MATERIALS AND METHODS}

The subject of research was groundwater from Quaternary formations characterized by a high concentration of total iron - amounting to 5.80 $\mathrm{mgFe} / \mathrm{dm}^{3}$, increased colour (B) - up to $38 \mathrm{mgPt} / \mathrm{dm}^{3}$ and turbidity (M) up to 21.1 NTU, and also an increased amount of organic substances (TOC from 3.60 to $6.40 \mathrm{mgC} / \mathrm{dm}^{3}$ ), and manganese (up to $0.60 \mathrm{mgMn} / \mathrm{dm}^{3}$ ). Iron (II) and iron (III) compounds were present in the water. The concentration of dissolved oxygen changed within the range of 0.50 to $0.60 \mathrm{mgO}_{2} / \mathrm{dm}^{3}$, and the $\mathrm{pH}$ value within the range of 6.84 to 7.37 (Tab. 1). These characteristics of the water were the cause of the unfavourable extent of the removal of iron compounds from it in the conventional system of underground water treatment. The turbidity and intensity of apparent and real colours of water proved the occurrence of iron in the form of colloidal and dissolved bonds with organic compounds, for the removal of which the coagulation process was used. The effectiveness of voluminal coagulation in groundwater treatment, after aeration and chemical oxidisation by potassium manganate (VII) was determined in the studies. The raw water was aerated with compressed air for a period of time of 15- minutes, 
obtaining a dissolved oxygen concentration at a level of about $10 \mathrm{mgO} / \mathrm{dm}^{3}$, that is, about $100 \%$ water saturation with oxygen. Also, chemically pure solution of potassium manganate (VII) was used to oxidise the Fe(II) ions; the oxidisation time amounted to $5 \mathrm{~min}$, and the dose of oxidising agent was determined in view of the concentration of $\mathrm{Fe}(\mathrm{II})$ at an amount equal to $100 \%$ of the stoichiometric demand. The coagulation was performed in water samples with a volume of $1-\mathrm{dm}^{3}$, applying 1-minute of rapid stirring at an intensity of 250-rev./min and 25-minute of flocculation with a stirring intensity of 30rev./min.

Table 1 . Groundwater quality indicators

\begin{tabular}{|l|c|c|c|c|}
\hline \multirow{2}{*}{ Indicator } & \multirow{2}{*}{ Unit } & \multicolumn{3}{c|}{ Value } \\
\cline { 3 - 5 } & & Minimum & Average & Maximum \\
\hline $\mathrm{pH}$ & - & 6.84 & - & 7.37 \\
\hline Dissolved Oxygen & $\mathrm{mgO}_{2} / \mathrm{dm}^{3}$ & 0.50 & 0.55 & 0.60 \\
\hline Colour & $\mathrm{mgPt} / \mathrm{dm}^{3}$ & 19 & 26 & 38 \\
\hline Turbidity & $\mathrm{NTU}$ & 1.73 & 4.50 & 21.1 \\
\hline Iron total & $\mathrm{mgFe} / \mathrm{dm}^{3}$ & 3.30 & 4.00 & 5.80 \\
\hline Iron (II) & $\mathrm{mgFe} / \mathrm{dm}^{3}$ & 2.80 & 3.40 & 4.00 \\
\hline Iron(III) & $\mathrm{mgFe} / \mathrm{dm}^{3}$ & 0.50 & 0.70 & 1.80 \\
\hline Manganese & $\mathrm{mgMn} / \mathrm{dm}^{3}$ & 0.20 & 0.29 & 0.60 \\
\hline TOC & $\mathrm{mgC} / \mathrm{dm}^{3}$ & 3.60 & 4.73 & 6.40 \\
\hline
\end{tabular}

Aluminium sulphate (VI) (SAL) and polyaluminium chloride (Flokor 1.2A) dosed in the form of water solutions were used as coagulants. The doses of coagulants were expressed as $\mathrm{mgAl} / \mathrm{dm}^{3}$. Six different doses of coaguants were selected $1,2,3,4,5$ and $6 \mathrm{mgAl} / \mathrm{dm}^{3}$. After the process of coagulation, the water samples underwent 1 hour of sedimentation. The physical-chemical composition of both the raw groundwater as well as treated water was determined according to the International Standard methods. The $\mathrm{pH}$ of the raw water and the purified water was determined with an WTW Multi Line P4 with an combination $\mathrm{pH}$ electrode with temperature corrections. The dissolved oxygen of the raw water and the purified water was determined with an WTW Multi 3410 SET 4 with an optical oxygen sensor FDOR 925 (Germany). Turbidity was measured using the Hach 2100N Turbidimeter - the nephelometric method. The colour (according to Pt scale), total iron, iron (II) concentrations were determined with the $\operatorname{Dr} 3900$ (HACH Lange) spectrophotometer. Iron (II) was measured using the 1,10 phenanthroline method. Total iron was measured using the same method except that a reducing reagent was also included in a reagent powder pillow to convert $\mathrm{Fe}$ (III) to $\mathrm{Fe}$ (II). The colour was indicated in accordance with ISO 7887-Method C [33]. Quartz 
cuvette with path length of light $50 \mathrm{~mm}$ was used. It was determinated after filtration of the water sample through a membrane filter of pore size $0.45 \mu \mathrm{m}$. Colour of the sample was calculated using following equation: $\mathrm{C}=\mathrm{A}_{410} / \mathrm{ad}\left[\mathrm{mgPt} / \mathrm{dm}^{3}\right]$. Where $\mathrm{C}$ is true color of the sample, $\mathrm{A}_{410}$-absorbance of the sample at $\lambda=410 \mathrm{~nm}$, a-specific absorption coefficient of the calibration solution of potassium hexachloroplatine and cobalt chloride $\left[\mathrm{mm}^{-1}\left(\mathrm{mgPt} / \mathrm{dm}^{3}\right)^{-1}\right]$, d-optical pathlength $(\mathrm{mm})$ [33]. The TOC was measured with a Shimadzu TOC analyzer. Manganese concentrations were determined with the atomic absorption method (Analyst 700, Perkin Elmer Company, US).

\section{RESULTS AND DISCUSSION}

\section{Efficacy of water treatment by oxidation and coagulation processes}

The effects of the removal of pollutants from the water after oxidisation with potassium manganate (VII) showed that the precipitating manganese (IV) oxide increased the effectiveness of the removal of pollutants from the water. Comparison of the effects of coagulation in the treatment of aerated water and water after oxidisation with potassium manganate (VII) showed that the application of potassium manganate (VII) as an oxidising agent was much better than oxidisation with compressed air regards to the degree of the reduction in colour, turbidity, concentration of iron, manganese and organic substances (Figs 1, 2 and 5).
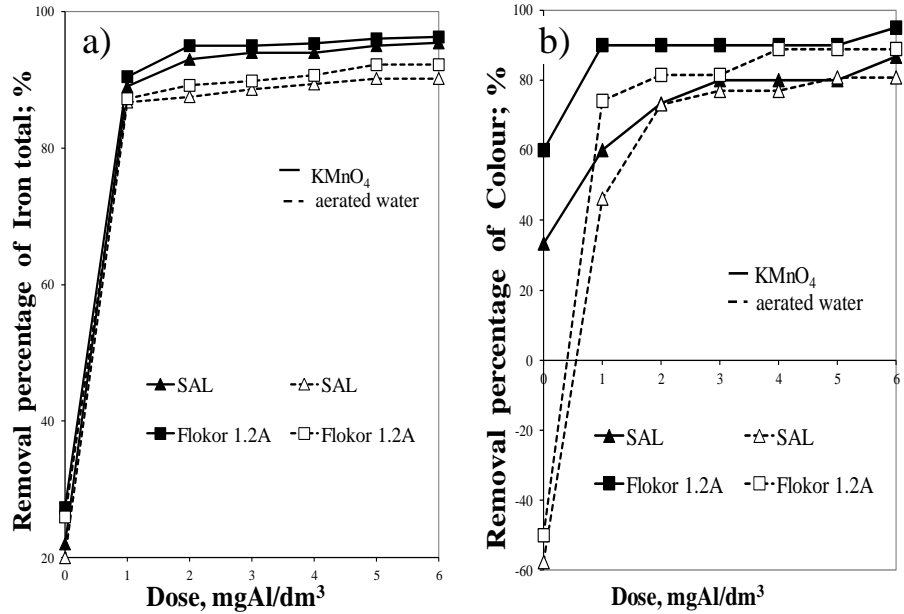

Fig. 1. Comparison of the effectiveness of coagulation in the reduction of the total iron concentration (a) and colour (b) in water after oxidisation with $\mathrm{KMnO}_{4}$ or after aeration 
Application of potassium manganate (VII) as an oxidizer, as compared with dissolved oxygen, was also beneficial because in the treated water $\mathrm{pH}$ did not grow. As a result of aeration the $\mathrm{pH}$ value of the treated water reached $\geq 8$ which may have caused a complete dissociation of organic substances, and at the same time may have created conditions for forming of colourful hardly sedimenting ferro-organic combinations. The lack of increase in the $\mathrm{pH}$ in water after oxidisation with potassium manganate (VII) $\left(\left(\mathrm{pH}=7\left(\mathrm{KMnO}_{4}\right)\right), \mathrm{pH}=8\left(\mathrm{O}_{2}\right)\right)$ and additionally precipitated manganese (IV) oxide was especially favourable in terms of the removal of the organic substances (Fig $2 b$ ).
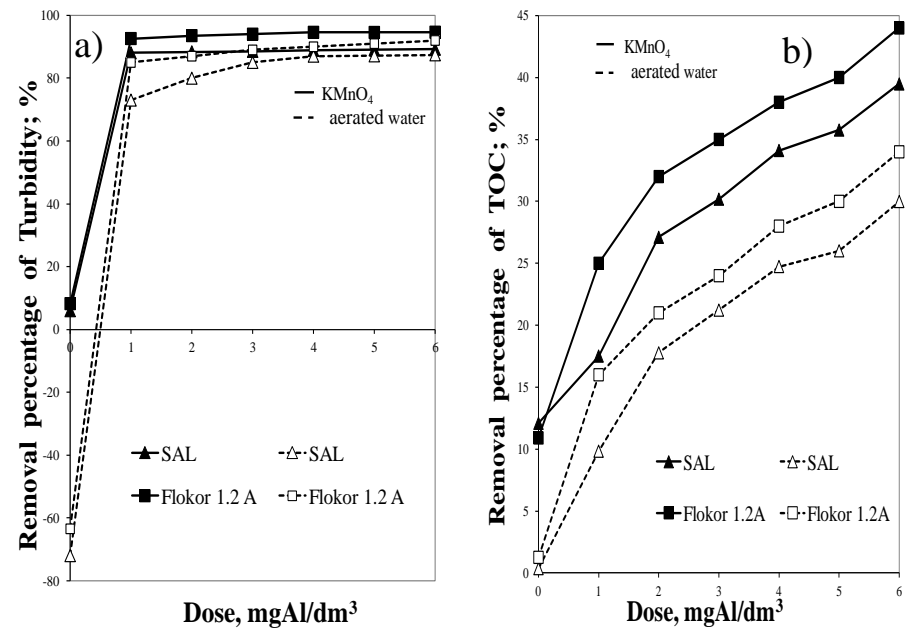

Fig. 2. Comparison of the effectiveness of coagulation in reducing the turbidity (a) and concentration of total organic carbon (b) in water after oxidisation with $\mathrm{KMnO}_{4}$ or after aeration

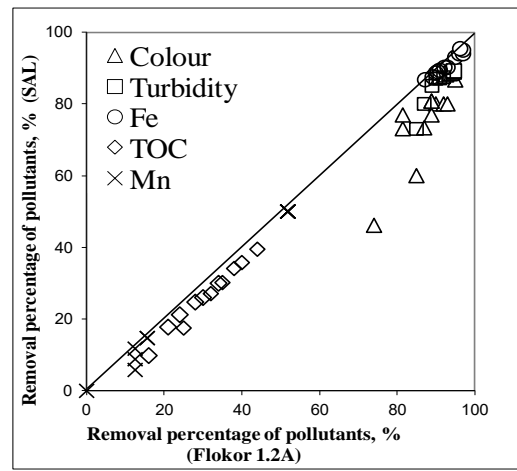

Fig. 3. The impact of the type of coagulants (SAL, Flokor 1.2A): on the effects of the removal of pollutants in the coagulation process after oxidisation with $\mathrm{KMnO}_{4}$ or after aeration 
According to Ficek and Vella [7] application of potassium manganate (VII) to drinking water treatment systems can help solve a number of problems. It is a versatile oxidant that will react with organic compounds easily breaking carbon-carbon double bonds and oxidizing functional groups. The comparison of the usefulness of the studied coagulants in the removal of pollutants from water after oxidisation of $\mathrm{Fe}(\mathrm{II})$ with potassium (VII) manganate, just as in the case of the treatment of aerated waters, confirmed the greatest effectiveness of coagulant which was prehydrolyzed with Flokor 1.2A (Figs 1-3).

Also, the concentration of the residual aluminium was determined in the studies. It was ascertained that also in this aspect, polyaluminium chloride was more useful than aluminium sulphate (VI). The lowest aluminium concentrations $\left(0.28-0.22 \mathrm{mgAl} / \mathrm{dm}^{3}\right)$ were found in water after oxidisation with potassium (VII) manganate and coagulation with coagulant Flokor 1.2A $\left(\mathrm{D}_{\mathrm{c}}=\right.$ $1-6 \mathrm{mgAl} / \mathrm{dm}^{3}$ ) (Fig. 4).
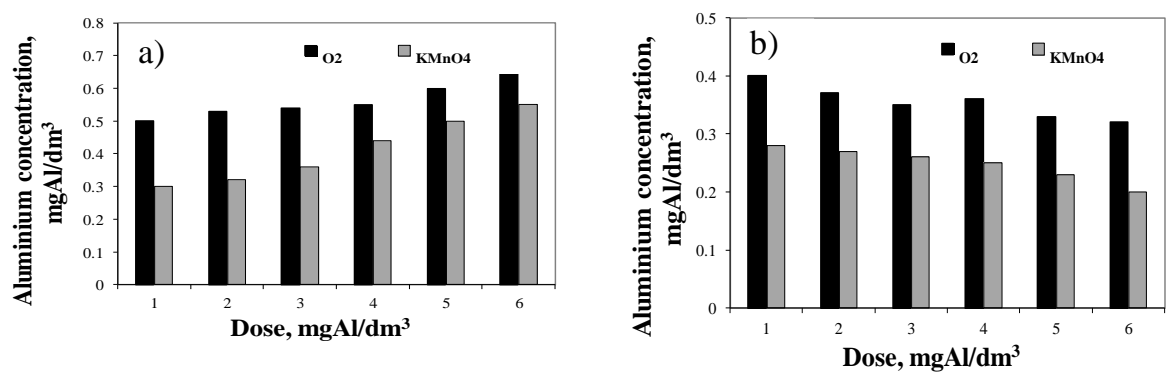

Fig. 4. The impact of the type and dose of coagulant and the oxidising agent on the change of aluminium concentration: a) SAL, b) Flokor 1.2A

Also according to Edzwald et al. [6] substitution of aluminium sulphate (VI) by polyaluminium chlorides reduced the concentration of aluminium residual in water after coagulation. Nowacka and Włodarczyk-Makuła [23] and Edzwald et al. [6] believe that polyaluminium chlorides are more effective than aluminium sulphate (VI). The higher efficiency of polyaluminium chloride than aluminium sulphate (VI) is attributable to the fact that the solutions of polyaluminium chloride contain (in addition to aluminium monomers) large quantities of polycationic products generated during prehydrolysis of aluminium, which effectively neutralize the negative charges of the colloids $[5,16,17]$. The degree of the removal of manganese from water samples in which potassium (VII) manganate was applied as the oxidising agent was constant and did not depend on the dose of the coagulant. On the other hand, in the case of preceding the coagulation with aeration the effectiveness of the removal of manganese was reduced together with an increase in the dose of the studied coagulants (Fig. 5). 


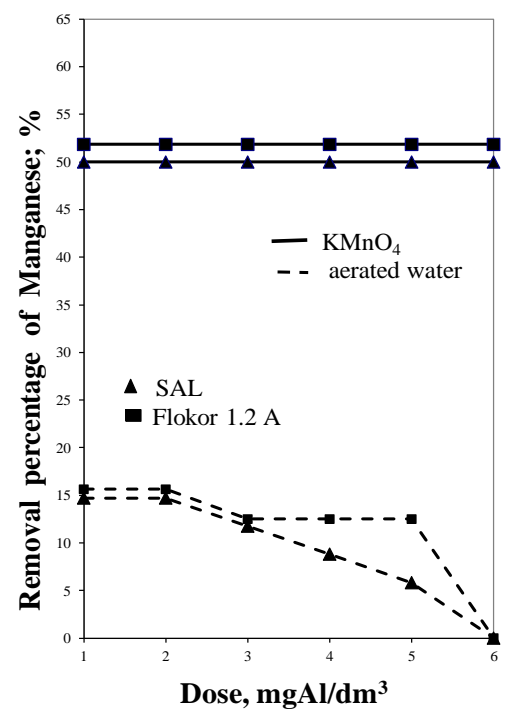

Fig. 5. The impact of the type and dose of coagulant and the oxidising agent used on the effectiveness of the removal of manganese from water

Analysis of the results of the studies presented in Table 2 showed that irrespective of the oxidising agent used, an increase in the effectiveness of coagulation and sedimentation in the removal of Fe(III) resulted in an increase in the degree of the removal of TOC, which proves the removal of $\mathrm{Fe}(\mathrm{III})$ together with the organic substances, and thus, the occurrence of iron in ironorganic bonds in water.

Table 2. Parameters of lineral regression between the amount of TOC removed and the amount of $\mathrm{Fe}(\mathrm{III})$ removed in the coagulation process

\begin{tabular}{|l|l|l|c|}
\hline $\begin{array}{c}\text { Type } \\
\text { of oxidant }\end{array}$ & \multicolumn{1}{c|}{$\begin{array}{c}\text { Type } \\
\text { of coagulant }\end{array}$} & Linear regression equation & $\begin{array}{c}\text { Coefficient of } \\
\text { determination } \\
\left(\mathrm{R}^{2}\right)\end{array}$ \\
\hline $\mathrm{O}_{2}$ & Flokor 1.2 A & $\eta \mathrm{TOC}=1.319 \eta \mathrm{Fe}(\mathrm{III})-98.101$ & 0.9501 \\
\cline { 2 - 4 } & SAL & $\eta \mathrm{TOC}=1.812 \eta \mathrm{Fe}(\mathrm{III})-147.12$ & 0.9465 \\
\hline $\mathrm{KMnO}_{4}$ & Flokor $1.2 \mathrm{~A}$ & $\eta \mathrm{TOC}=1.850 \eta \mathrm{Fe}(\mathrm{III})-121.40$ & 0.9688 \\
\cline { 2 - 4 } & SAL & $\eta \mathrm{TOC}=1.506 \eta \mathrm{Fe}(\mathrm{III})-88.805$ & 0.9457 \\
\hline
\end{tabular}

In the water samples in which $\mathrm{O}_{2}$ or $\mathrm{KMnO}_{4}$ were used for oxidisation of $\mathrm{Fe}(\mathrm{II})$, no relationship between the effectiveness of the removal of manganese and TOC in the coagulation process. This confirms the opinion of Albrektiene [2] that manganese doesn't form colloids complexes with fraction of organic matters. The amount of colour substances removed from $\mathrm{Fe}(\mathrm{III})(\Delta \mathrm{B} / \Delta \mathrm{Fe}(\mathrm{III}))$ was 
greater in the water samples after oxidization with $\mathrm{KMnO}_{4}$ than after aeration and they increased together with a dosed of coagulants (Table 3 ).

Table 3. Influence of the type and dose of coagulant and the type of oxidizing agent on the amount of colour pollutant $(\mathrm{mg})$ removed from $1 \mathrm{mg}$ of $\mathrm{Fe}(\mathrm{III})(\Delta \mathrm{B} / \Delta \mathrm{Fe}(\mathrm{III}))$

\begin{tabular}{|l|l|c|c|c|c|c|c|}
\hline \multirow{3}{*}{$\begin{array}{c}\text { Typeof } \\
\text { oxidant }\end{array}$} & \multirow{2}{*}{$\begin{array}{c}\text { Type } \\
\text { of coagulant }\end{array}$} & \multicolumn{6}{|c|}{$\Delta \mathrm{B} / \Delta \mathrm{Fe}(\mathrm{III})$} \\
\cline { 3 - 8 } & & 1 & 2 & 3 & 4 & 5 & 6 \\
\hline \multirow{2}{*}{$\mathrm{O}_{2}$} & Flokor 1.2 A & 9.18 & 8.87 & 8.70 & 8.57 & 8.26 & 8.45 \\
\cline { 2 - 8 } & SAL & 4.80 & 6.88 & 7.19 & 7.19 & 7.64 & 7.66 \\
\hline $\mathrm{KMnO}_{4}$ & Flokor 1.2A & 9.52 & 9.82 & 9.99 & 10.13 & 10.20 & 10.25 \\
\cline { 2 - 8 } & SAL & 9.37 & 9.02 & 8.69 & 8.51 & 8.39 & 8.50 \\
\hline
\end{tabular}

\section{CONCLUSIONS}

The test results analysis leads to the following conclusions:

1. The effectiveness of the process of coagulation for the removal of iron, manganese and organic substances from underground water depended on the type of oxidizing agent used and the type of coagulant.

2. Better results in purifying the water were obtained with the use of a prehydrolysed coagulant Flokor 1.2 A than sulphate (VI) of aluminium. The highest concentration of the aluminium residual was found in samples subject to coagulation with aluminium sulphate (VI).

3. Independently of the type of coagulants used and the type of oxidizing agent, iron compounds were removed together with organic substances, which proved that they are present in water in the form of colloidal ironorganic compounds. No relationship between the effectiveness of the removal of manganese and organic substances in the coagulation process.

4. A greater efficiency in removing iron, manganese and organic substances in oxidation and coagulation processes was achieved when applying potassium manganate (VII) as an oxidizer, because one of the oxidation products was manganese oxide (IV) precipitating from water.

5. The experimental results suggested that manganese oxide (IV) may adsorb naturally occurring organic materials through surface bonding to form bigger particulates, thus increasing the floc density and improving the removal of organic particulates and the inorganic particles such as iron and manganese.

6. The degree of the removal of manganese from water samples in which potassium (VII) manganate was applied as the oxidising agent was constant and did not depend on the dose of the coagulant but the removal of manganese depended on the amount of precipitated manganese oxide (IV). 


\section{REFERENCES}

1. Albrektiene R., Rimeika M., Lubyte E.: The removal of iron-organic complexes from drinking water using coagulation process, The 8 th International Conference Environmental Engineering, May 19-20, Vilnius, Lithuania 2011.

2. Albrektiene R., Rimeika M., Grazeniene R.: Organic fractions and metalorganic complexes in the groundwater, The 9th International Conference Environmental Engineering, May 22-23, Vilnius, Lithuania 2014.

3. Ciupa R., Dzienis L.: Zastosowanie $\mathrm{KMnO}_{4}$ i $\mathrm{ClO}_{2}$ do usuwania organicznych form żelaza $i$ manganu $z$ wód podziemnych, Ochrona Środowiska, 1/60 (1996) 25-26.

4. Civardi J., Tompeck M.: Iron and manganese removal handbook. Second Edition. Denver, CO: American Water Works Association 2015.

5. Dempsey B. A., Ganho R. M., O Melia C. R.: The coagulation of humic substances by means of aluminum salts, Journal American Water Works Association 76/4(1984) 141-150.

6. Edzwald J., Perntsky D., Paramenter W.: Polyaluminum coagulants for drinking water treatment, chemistry and selection, Chemical Water and Wastewater Treatment VI Berlin 2000.

7. Ficek K., Vella P.: Potasium permanganate the oxidation solution to many water treatment problems, Zaopatrzenie w Wodę Miast i Wsi, Jakość i Ochrona Wód, Kraków 2000, 673-684.

8. Gonczarow T.O., Kołosow I. W., Kaplin W.: O formach nachorzdjenija metallow w powjerchnostnych wodach, Gidrometeoizdat, 77 (1982) 73-89.

9. Huang C., Shiu H.: Interactions between alum and organics in coagulation, Colloids and Surface 113 (1996) 155-163.

10. Jobin R., Ghosh M.: Effect of Buffer Intensity and Organic Matter on the Oxygenation of Ferrous Iron, JAWWA 64 (1972) 590-595.

11. Knocke W.R., Van Benschoten J. E., Kearney M.J., Soborski A.W., Reckhow D. A.: Kinetics of manganese and iron oxidation by potassium permanganate and chlorine dioxide, JAWWA, 6 (1991) 80-87.

12. Knocke W.R., Shorney H.L., Bellamy J.D.: Examining the reactions between soluble iron. DOC and alternative oxidants during conventional treatment, JAWWA, 1 (1994) 117-127.

13. Krupińska I., Świderska-Bróż M.: Effect of the presence of organic substances on the extent of iron compound removal from water via oxidation and sedimentation processes, Ochrona Środowiska, 30(2008) 3-7. 
14. Krupińska I.: Suitability of Coagulation for Treatment of Groundwater, Rocznik Ochrona Środowiska, 14 (2012) 491-501.

15. Krupińska I., Kowalczyk W., Szczepaniak G.: Effect of coexistence ratio of organic substances and total iron in groundwater on its treatment efficacy, Ochrona Środowiska, 35(2013) 27-34.

16. Krupińska I.: Effect of Temperature and $p H$ on the Effectiveness of Pollutant Removal from Groundwater in the Process of Coagulation, Ochrona Środowiska, 37(2015) 35-42.

17. Krupińska I.: The impact of the oxidising agent type and coagulant type on the effectiveness of coagulation in the removal of pollutants from underground water with an increased content of organic substances, Journal of Environmental Engineering and Landscape Management, 24(2016) 70-78.

18.Krupińska I.: Effect of organic substances on the efficiency of $\mathrm{Fe}(\mathrm{II})$ to $\mathrm{Fe}(I I I)$ oxidation and removal of iron compounds from groundwater in the sedimentation process, Civil and Environmental Engineering Reports, 26 (2017) 15-29.

19. Macioszczyk A., Dobrzyński D.: Hydrogeochemia strefy aktywnej wód podziemnych, PWN, Warszawa 2002.

20. Munter R.,Overbeck P., Sutt J.: Which is the Best Oxidant for Complexed Iron Removal from Groundwater: The Kogalym Case, Ozone: Science and Engineering, 30 (2008) 73-80.

21. Nawrocki J., Biłozor S., Kalkowska I.: Uboczne produkty utleniania domieszek wód, Ochrona Środowiska, 3/50 (1993) 37-40.

22. Nawrocki J., Biłozor S.: Uzdatnianie wody, procesy chemiczne i biologiczne, Wyd. Nauk. PWN, Warszawa-Poznań 2010.

23. Nowacka A., Włodarczyk-Makuła M., Macherzyński B.: Comparison of effectiveness of coagulation with aluminum sulfate and pre-hydrolyzed aluminum coagulants, Desalination and Water Treatment, 52 (2014) 38433851.

24. Pandey A. K., Pandey S. D., Mstra V.: Stability constants of metal-humic acid complexes and its role in environmental detoxification, Ecotoxicology and Environmental Safety, 47(2000)195-200.

25. Perchuć M.: Wspótudziat żelaza i kwasów humusowych $w$ ksztaltowaniu sposobu uzdatniania barwnych wód podziemnych, Oficyna Wydawnicza Politechniki Warszawskiej, Warszawa 2004.

26. Schnitzer M., Skinner S. I. M.: Organo-metallic interactions in soils. Stability constants of $\mathrm{Cu}^{2+}, \mathrm{Fe}^{2+}$ and $\mathrm{Zn}^{2+}$ fullvic acids complexes. Soil Science 102 (1966) 102-361.

27. Sharma, S.K.: Adsorptive Iron Removal from Groundwater, Swets \& Zeitlinger B.V, Lisse, The Netherlands 2001. 
28. Skoczko I., Piekutin J., Roszczenko A.: Usuwanie z wody związków żelaza i manganu metoda filtracji na wybranych złożach, Rocznik Ochrona Środowiska, 17(2015) 1587-1608.

29. Teh Fu Yen: Chemical processes for environmental engineering, Imperial College Press, London 2007.

30. Urbanowska A., Kabsch-Korbutowicz M.: Characteristics of natural organic matter removed from water along with its treatment, Environment Protection Engineering, 42(2016) 183-195.

31. Urbanowska A., Kabsch-Korbutowicz M.: The properties of NOM particles removed from water in ultrafiltration, ion exchange and integrated processes, Desalination and Water Treatment, 57(2016) 13453-13461.

32. Van Benschoten J. E., Edzwald J. K.: Chemical aspects of coagulation using aluminum salts-II. Coagulation of fulvic acid using alum and polyaluminum chloride, Water Research, 24 (1990) 1527-1535.

33. Water quality-Examination and determination of colour. International standard ISO 7887, 2011.

\section{WPŁYW MNANGANIANU (VII) POTASU NA SKUTECZNOŚĆ KOAGULACJI \\ W USUWANIU ZWIĄZKÓW ŻELAZA I MANGANU Z WODY PODZIEMNEJ O PODWYŻSZONEJ ZAWARTOŚCI SUBSTANCJI ORGANICZNYCH}

\section{Streszczenie}

Skuteczności usuwania żelaza i manganu $\mathrm{z}$ wody podziemnej o podwyższonej zawartości substancji organicznych zależała od rodzaju stosowanego utleniacza (tlen rozpuszczony lub manganian (VII) potasu) oraz dawki i rodzaju koagulantu (siarczan (VI) glinu lub chlorek poliglinu). Spośród stosowanych sposobów utleniania żelaza (II) przed procesem koagulacji lepsze efekty $\mathrm{z}$ uwagi na usuwanie żelaza, manganu i substancji organicznych zapewniło utlenianie manganianem (VII) potasu niż napowietrzanie. Skuteczność badanych koagulantów w usuwaniu zanieczyszczeń zwiększała się wraz ze wzrostem ich dawki, a lepsze efekty oczyszczania wody podziemnej zapewnił koagulant wstępnie zhydrolizowany Flokor 1,2A niż siarczan (VI) glinu.

Słowa kluczowe: wody podziemne, żelazo, mangan, substancje organiczne, manganian (VII) potasu, koagulacja

Editor received the manuscript: 9.10 .2017 